\title{
Two-Dimensional Hydraulic Modeling and Geotechnical Analysis of Earthen Regulation Dams Located at Arroyo Las Viboras Watershed in a Major Transboundary Mexico-USA Metroplex: How an Ordinary Rain Event Caused Major Damage Related to Extraordinary Flooding?
}

\author{
Oscar Sotero Dena Ornelas, Diane Irene Doser, \\ Oscar Fidencio lbañez Hernández, \\ Griselda Janeth Obeso Cortez and \\ Miguel Angel Galdean Vega
}

Additional information is available at the end of the chapter

http://dx.doi.org/10.5772/intechopen.68853

\begin{abstract}
Despite low annual precipitation rates, major cities located in deserts are prone to flash flooding events, which incur important economic costs and in some cases loss of human life. The northern Chihuahua desert metroplex of Ciudad Juarez, Chihuahua-El Paso, Texas, is a region where seasonal summer rains result in flash flooding. One of the most important flooding zones in Ciudad Juarez occurs at the Arroyo Las Viboras. Detailed light detection and ranging (LIDAR) terrain models were incorporated during two-dimensional modeling to understand flow conditions for two specific ordinary rain events. In addition, electrical resistivity tomography and seismic geophysical studies were conducted to examine if the hydraulic infrastructure was properly emplaced from a geological and geotechnical perspective. The results showed that Las Viboras watershed is almost hydrologically unprotected since the major dam is not regulating water flow volumes. The Camino Real transmountain road is improperly acting as a retention wall and geotechnical and geophysical findings indicate that Puerto La Paz dam has to be moved to a new location since it is currently located on top of plastic clays. El Filtro dam poses a higher risk because.Finally, three more dams are required to be constructed upstream in order to ensure hydrological resilience of the watershed.
\end{abstract}

Keywords: desert, flash flooding, bi-dimensional modeling, geotechnics, resilience 


\section{Introduction}

Despite low annual precipitation rates of less than $300 \mathrm{~mm} /$ year [1], the urbanized areas of the northern Chihuahua desert paradoxically experience flash flooding events as a consequence of seasonal summer rains that often release more than $50 \%$ of the yearly rain in only 48 hours [2]. The main population center located in this semiarid region is the twin city, transboundary metroplex formed by Ciudad Juarez, Chihuahua and El Paso, Texas. The denser populated area corresponds to the Mexican city of Juarez, with more than 1.5 million inhabitants distributed along the western piedmont of the Sierra de Juarez (SDJ) mountain range and the Rio Grande River (RGR) basin's main depocenter, defined by the axis of the Rio Grande River (Figure 1). This growing population experiences severe property damage on a yearly basis as consequence of seasonal rain events.

Ciudad Juarez's hydrology is divided into eight basins according to the municipal research and planning agency [2]. Although all the basins become problematic flooding areas during seasonal rains, flooding at Las Viboras watershed's downstream area, located in the Anapra

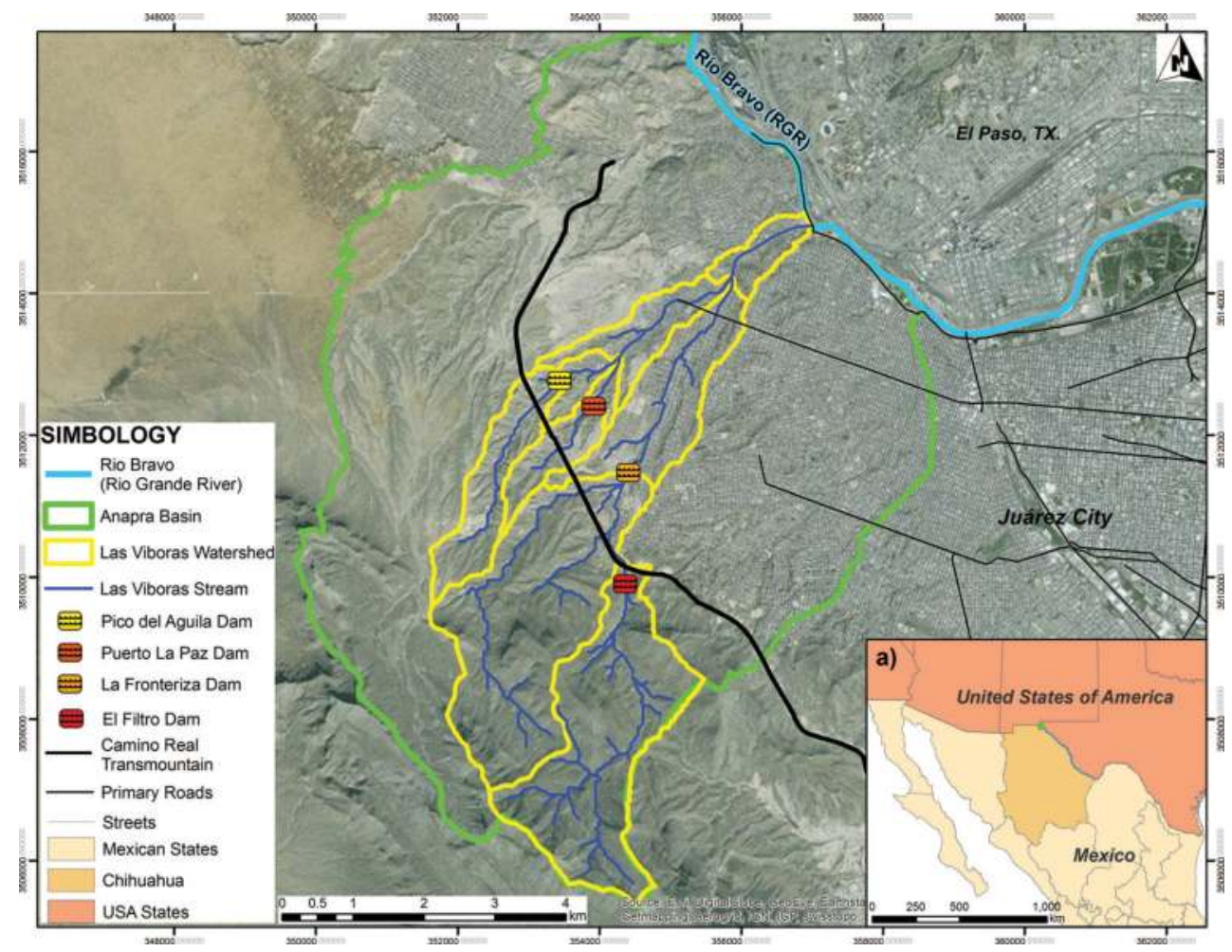

Figure 1. Location of the Cd. Juarez, Chihuahua-El Paso, Texas Metroplex and Las Viboras watershed, earthen regulation dams and hydrologic network. 
basin (Figure 1), has been historically one of the most complicated water volumes to be managed efficiently. Anapra is the only basin in Juarez that drains directly into the RGR. The hydrological protection of Las Viboras Arroyo Watershed depends on four existent earthen regulation dams: Pico del Aguila, Puerto La Paz, La Fronteriza and El Filtro (Figure 1). However, ordinary rain events in November 2016 recorded important flooding and high flows at the Rio Grande River delivery point, precisely indicating a lack of flow regulation. In this research, we have combined a holistic approach by integrating hydrology, bidimensional hydraulic modeling and geological-geophysical methods to investigate how the ordinary rain event of November 4, 2016 resulted in severe loss of life and property in Las Viboras Arroyo watershed. We also explored what would happen if El Filtro dam would have failed during a 500 year return period (YRP) event and how the Camino Real transmountain road culverts operate under hydraulic stress.

\section{Background}

\subsection{Hydrology}

Ciudad Juarez's hydrology is divided into eight basins according to the municipal research and planning agency [2]. Three basins are located at the Sierra de Juarez (SDJ): Anapra, Centro and Jarudo, whereas the Aeropuerto basin, adjacent to Jarudo basin, is located in a nearly flat area. The Chamizal and Rio Bravo basins are located next to the Rio Grande River (RGR), and the Barreal and Acequias basins are of endhorreic type.

As expected, the hydrological drainage network is chiefly controlled by the topography of the SDJ. This mountain range reaches elevations of $1800 \mathrm{~m}$ above sea level, resulting in a relative height difference of nearly $470 \mathrm{~m}$ with respect to the surrounding basin floors and of $490 \mathrm{~m}$ with the RGR.

In spite of the dramatic topographic contrast, the only basin draining directly into the RGR is the Anapra. Las Viboras Watershed is the main watershed in Anapra basin. This system, Las Viboras, collects runoff volume from a catchment area of nearly $22 \mathrm{~km}^{2}$ [3]. Although the watershed is supposed to be protected by three regulation dams, historically this watershed has experienced some of the greatest damage associated with hydro-meteorological events in Ciudad Juarez. In 2006, during a 10 year return period (YRP) event, the hydrological resilience of this watershed was demonstrated as being poor since the most important dam, in terms of capacity, was overtopped during the rain event, requiring authorities to evacuate population located downstream due to the imminent risk of the dam's wall breaking [3]. After the rain event, the dam had to be artificially breached by constructing a $70 \mathrm{~m}^{3} / \mathrm{s}$ channel to prevent water accumulation. As a temporary solution a new retention wall was emplaced upstream of the dam to mitigate water flow. However, and regretfully, the temporary solution became permanent. Now, Las Viboras system seems to be even more compromised, in hydrological terms, than in 2006, as consequence of the lack of infrastructure maintenance and a poor urbanization plan that allowed several new low-income neighborhoods to be developed downstream without regard to the hydrological safety. 


\subsection{Geologic and tectonic setting}

Structurally, the major tectonic feature controlling recent basin formation and deposition style in the area is the Cenozoic Rio Grande Rift. Extension in the rift has produced an asymmetric intramontane basin system controlled by normal faulting that has overprinted the Laramiderelated compressional structures. Among the Laramide-related structures, the Sierra de Juarez is the major landmark in the region. The stratigraphic sequence of the SDJ is composed of Mesozoic geologic units of a transgressional marine sequence deposited in the Chihuahua Trough $[4,5]$. Shales and sandstones characterize the lower part of this sequence, whereas the middle part is formed of limestones and shales, topped with post reef limestone facies [6]. Volcanic activity occurred in the Paleocene with the emplacement of acid to intermediate composition intrusive igneous rocks. Well-consolidated deposits, such as conglomerates, silts and sands, were deposited discordantly during the Plio-Pleistocene [7].

The top of the stratigraphic column is composed of interbedded sequences of coarse clastic sediments and fine grain materials transported from the more topographically elevated areas and deposited in the basins as alluvial, lacustrine or aeolian sediments. The basin fill is mainly Pliocene with some thinner quaternary units on top.

Basement units that outcrop in the nearby SDJ include the Cretaceous Cuchillo, Benigno, Lagrima and Finlay formations [8]. Each formation has very distinctive hydraulic and mechanical properties as a consequence of the compositional transitions between massive coral limestones (Benigno and Lagrima formations) to interbedded limestone-sandstone (Cuchillo) and limestone-shale (Finlay) formations that are less permeable.

In terms of geologic elements to provide structural support for proper dam foundation, emplacement and construction, the topographic closures flanked by competent rock units are present only in the highlands of SDJ. The best geological units, the massive limestone rock units are related to the Aurora group, which are the most competent. On the other hand, flaky shales (Ojinaga and La Casita formations) associated with Turonian and Tithonian horizons, respectively, should be avoided $[8,9]$.

\section{Methodology}

First, we used a precise light detection and ranging (LIDAR) derived digital terrain model (DTM) to determine watershed boundaries and update other physiographic elements for calculations of surface hydraulic flow. We also modeled the flow conditions through bidimensional hydraulic modeling of the Naviers-Stokes equations using the IBER software package to investigate how hydraulic structures such as culverts and earthen regulation dams are actually operating and why dangerous high velocity and turbulent flows are recorded downstream even in ordinary rain events. In addition, we also investigated the subsurface geologic setting by conducting high-resolution electrical resistivity tomography [10], which combined with seismic refraction and S-wave velocity studies [11], allowed us to infer the foundational and structural integrity of Camino Real culverts and regulation dams located in Las Viboras stream drainage system. 
The first step in this study consisted of modeling the hydrology of the watershed to estimate the runoff volume transported by Las Viboras watershed drainage network for ordinary rains. Then, once the hydraulic flow was calculated, geological, geophysical and geotechnical studies were conducted at several structures.

\subsection{Hydrologic modeling}

To calculate the total runoff flow and water volume collected along the drainage network of Las Viboras watershed for ordinary events, we distributed a 2 YRP event, or 50\% probability of exceedance rains in 24 hours, across the watershed. The watershed boundary was defined from a high resolution LIDAR $1 \mathrm{~m} \times 1 \mathrm{~m}$ cell size DTM utilizing the software package HecGeoHMS [12], which runs on the GIS software platform ArcGIS.

The watershed geometry, drainage network and the physiographic parameters: area $\left(\mathrm{km}^{2}\right)$, slope (10-85\%), length (m), concentration time (s) and lag time (s) were obtained from the Geo-HMS run and then validated by hand calculations. The runoff and/or infiltration were estimated applying the curve number $(\mathrm{CN})$ method, also referred as "Soil Conservation Service (SCS) runoff Curve number" [13], which defines the rain abstraction or how much rain infiltrates into the ground in terms of the soil group, hydrological conditions and landuse of the catchment area. Both the SCS CN and the impervious percentage were derived from high-resolution aerial imagery analysis and fieldwork. The precipitation-runoff transformation, hydrogram estimation and hydraulic parameters (flow and volume) at each hydrologic element were estimated as a result of the hydrologic simulation calculated from storm data for 2, 50, 500 and 10,000 YRP and physiographic parameters as input data into the HMS software package [14].

\subsection{Hydraulic modeling}

Because of the complexity of Las Viboras arroyo system, we decided to apply two-dimensional modeling to simulate arroyo hydraulics. The software utilized (IBER) for the calculations solves the 2D Saint-Venant equations [15] using the finite volume method, which relies on a nonstructured finite discretization of the terrain. The mesh representation obtained in this way allows the software to be able to represent almost any surface geometry, being able then, to model subtle river features. To perform the calculation, a $1 \mathrm{~m} \times 1 \mathrm{~m}$ DTEM derived from LIDAR data was utilized, the hydrologic parameters were input as a rain hyetograph for 2 and 500 YRP rain events, and bed roughness was modeled with manning roughness coefficients. The results are a grid representation of the output parameters such as water depth, velocity, Froude number, etc.

\subsection{Geoscience: geology, geophysics and geotechnical}

Geological studies are traditionally applied to determine the best wall dam emplacement location based upon topographic conditions, water-tightness of the reservoir, slope stability along the reservoir perimeter and availability of construction materials. The emplacement depends upon the dam foundation requirements, which in turn, are a function of the type of dam, dynamic moduli of the soil such as strength and deformation, depth to foundation and 
geohydrological properties such as permeability. In this case, since the Earthen Regulation Dams (ERD) were already constructed and information about their construction process is no longer available, geoscience approaches, mainly geophysical methods to determine geotechnical parameters, were applied not only to infer foundation characteristics but also to reveal, in an indirect way, the structural integrity of the culverts and three dams. More specifically, three geophysical methods were applied: Electrical Resistivity Tomography, Seismic Refraction and multichannel analysis of seismic waves (MASW).

Multielectrode electrical resistivity tomography (ERT) is a geophysical method that allows the user to infer the subsurface conditions in terms of the electrical contrast existing between different subsoil and geologic units. The contrast relies primarily on the grain size, water and mineralogical content of the units [16]. Therefore, this approach is appropriated to infer conditions related to earthen dams and foundation [22]. The high resolution data were collected along several profiles atop each dam's crest. We used a Terrameter LUND System with electrodes connected every $2 \mathrm{~m}$ to a multicore set of cables attached to a selector switch that controls the injection of current and ground resistance readings in accordance with a predetermined acquisition protocol. The ABEM instrument computer automatically selects the current injection, which ranges from 200 to $500 \mathrm{~mA}$. To obtain a reliable measurement of the ground resistance, 4 stacks per reading were averaged to obtain the actual recorded resistance value. The electrode arrays applied in the field were the Wenner and dipole-dipole configurations. Details of these arrays can be found in Refs. [10, 19].

Once the data were collected in the field, the electrical resistance field for each layout was geometrically corrected using the software package ERICGRAPH@ [18]. The apparent resistivity pseudosections were then inverted using a robust L1 norm algorithm, which minimizes the sum of the absolute values of the resistivity field spatial variations in order to map lateral heterogeneities [10]. The inversion was then implemented with the computational package RES2DINV to obtain the true electrical resistivity field and true depth of penetration sections that gave the least possible error between the observed and calculated data.

Editing of the noisy data and half electrode spacing cell width was applied during modeling since the data showed high surface resistivity variations [19]. As a last processing step, the inverted data were corrected for topographic effects and converted into ASCII format to develop a geographically referenced geoelectrical database. This was further post-processed in Oasis Montaj to render a resistivity voxel to better visualize the underground electrical resistivity distribution.

Seismic studies were conducted because the elastic properties of soils and subsurface can be inferred by properly mapping both compressional and shear wave velocity fields [11, 20]. The dynamic moduli: shear modulus, Young's modulus and Poisson's ratio provide a characterization of the soil-structure interaction and liquefaction potential of subsurface layers [20]. In this study, the seismic refraction lines were deployed with a geophone separation of $6 \mathrm{~m}$, and the MASW lines with the same length, except for the culvert analysis, where a $3 \mathrm{~m}$ spacing between geophones were applied. The processing of the compressional velocity $(V p)$ field consisted in the picking of first arrivals observed at each shot gather [21]. Then a tomographic inversion iterative process was applied to minimize the error misfit, since abrupt lateral variations were expected due to topographic and subsurface heterogeneities. For the S-wave dispersion 
studies (MASW), the dispersion curve was extracted by analyzing all traces in a shot gather and applying the Tau-P transform to obtain a coherent energy section relating Vs with frequency. The dispersion curve picked from the $V s$-frequency spectra was then inverted for a 1D depth-velocity (Vs) model. By then applying this procedure from one shot gather to another and using a common mid point (CMP) mapping of the seismic energy, we were able to generate a $2 \mathrm{D}$ section representing the shear wave velocity field.

\section{Results}

\subsection{Hydrology}

One of the main results of the hydrologic analysis of Las Viboras watershed shows how the paving process, linked to the urban development, has negatively affected the hydraulic condition of this watershed, since almost all the rain volume is conveyed downstream as runoff as consequence of the increase in impervious surfaces. According to the hydrologic modeling parameters, this watershed has a catchment area of $22 \mathrm{~km}^{2}$. It is intended to be hydrologically protected by four regulation structures: The Pico del Aguila dam, regulating the north branch runoff flowing down from the SDJ, the Puerto La Paz dam, regulating volumes from the central branch of Las Viboras drainage system, La Fronteriza dam, regulating flow from the south-central and southern branches of Las Viboras and El Filtro, regulating upstream flow on the southern branch of Las Viboras. As consequence of the 10 YRP event of 2006, La Fronteriza dam failed by overtopping. It is now breached to avoid water accumulation since the dam is structurally compromised. The El Filtro dam, located upstream, was then emplaced to temporarily regulate the southern branch runoff, thus decreasing the hydrologic pressure downstream. We modeled each hydraulic structure, including Earth Regulation Dams and culverts, to determine their hydraulic operation, including storage, pool elevation, inflow and outflow. The dams were analyzed for ordinary rains (2 YRP) up to extreme events (10,000 YRP), whereas culverts were analyzed for 500 YRP rain events. The hydraulic operation for each dam for 500 YRP and 10,000 YRP rains is shown in Figure 2.

\subsubsection{Culverts}

The natural drainage system of the Sierra de Juarez was modified as consequence of the construction of the transmountain road, El Camino Real, in 2008. In the area covered by the Las Viboras system watershed, there are 10 culverts to allow runoff to freely flow downstream. The slopes of those structures are greater than $3 \%$, and depending on the flow, they are either pipelines or concrete rectangular structures with a cross section of $4.5 \mathrm{~m} \times 4.5 \mathrm{~m}$. The hydrologic analysis of the culverts showed that they operate satisfactorily up to rain events of 500 YRP. However, the culvert located at the discharge of the El Filtro dam shows that downstream of El Camino Real, the discharge channel makes a very sharp turn, almost $80^{\circ}$ to the north. Two-dimensional hydraulic modeling is required to determine if there is a hydraulic jump as a consequence of the sharp channel geometry. 


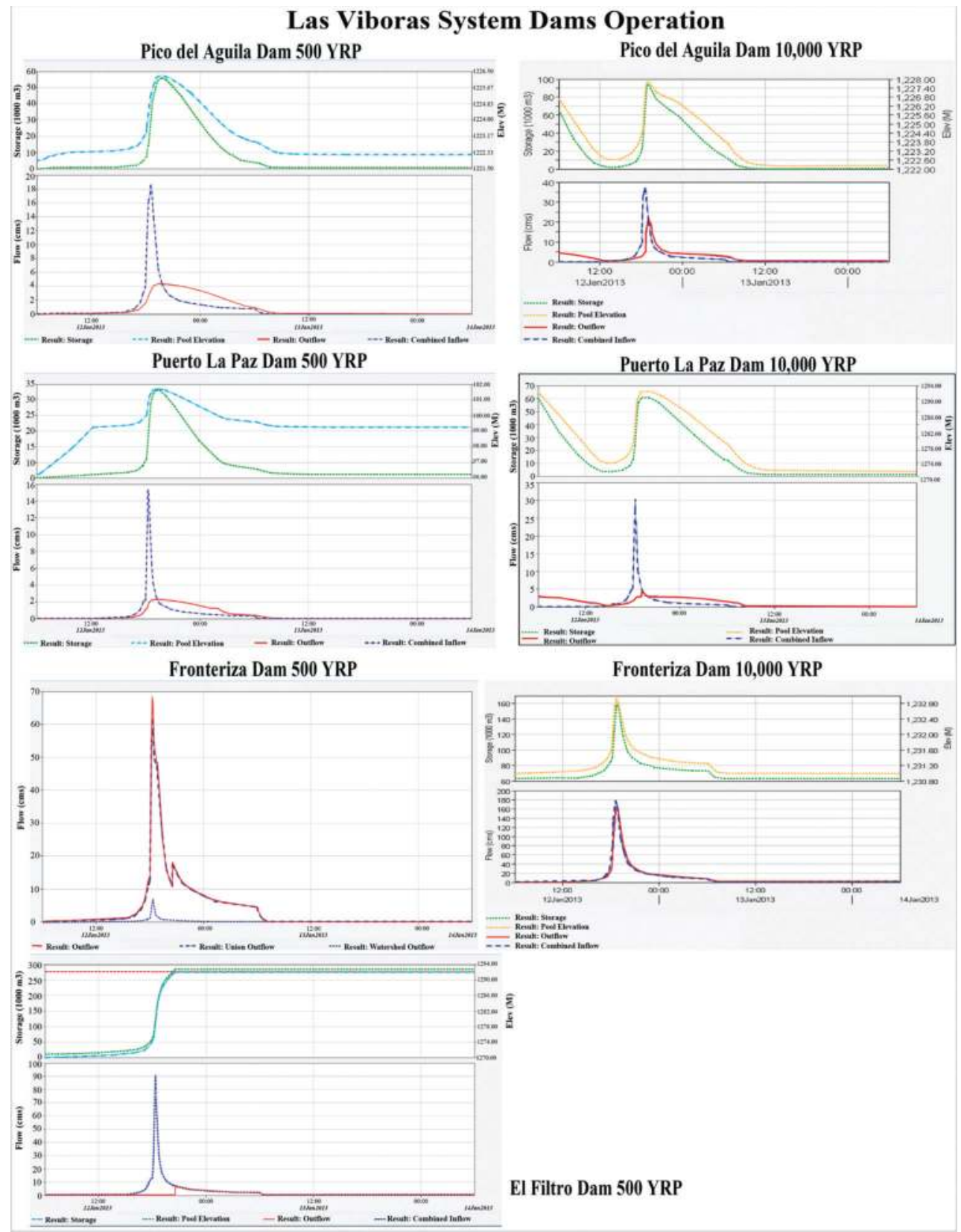

Figure 2. Models of hydraulic operation of dams for 500-10,000 YRP. The results were obtained by 1D hydrologic modeling. 


\subsubsection{ERD Pico del Aguila}

The Pico del Aguila dam has both a riser spillway and emergency spillway. The outlet pipeline has a diameter of $75 \mathrm{~cm}$. The dam crest reaches an elevation of $1221.50 \mathrm{~m}$ above sea level and the maximum impoundment capacity is $61,226 \mathrm{~m}^{3}$. The GEOHMS model shows that the total catchment area for this hydraulic structure is $2.11 \mathrm{~km}^{2}$, and the model results indicate that this structure operates properly for ordinary rains and extraordinary rain events of up to $500 \mathrm{YRP}$ with a freeboard of $1.55 \mathrm{~m}$. However, for extraordinary or extreme events, such as the 10,000 YRP, the hydraulic operation is seriously compromised since the water flow would overtop the dam's wall, eventually breaching the structure.

\subsubsection{ERD Puerto La Paz}

This regulation dam is designed to regulate the runoff volumes moving downstream from the southern central part of the highlands of Las Viboras system, which are located at the scarped flanks of the Sierra de Juarez. The results of the hydrologic run show that the dimensions of the reservoir and wall of this regulation dam are able to operate satisfactory up to a 500 YRP rain, with a freeboard of $1.55 \mathrm{~m}$. However, the analysis for a 10,000 YRP rain with full reservoir indicates that the structure will be overtopped by the water volume. Thus, the dam is not hydraulically operating properly according to Mexican law, which requires that any dam should be able to transit a hydrogram corresponding to a 10,000 YRP runoff, assuming that the reservoir is full. In spite of this failure in hydrological safety of the Puerto La Paz dam for extreme events, the structure can very efficiently handle ordinary rains.

\subsubsection{ERD El Filtro}

This structure is not even a dam since it lacks a riser spillway, emergency spillway and outlet. This structure is just a pile of dirt and pieces of rock obtained from the materials excavated during construction of El Camino Real that were piled up at the pilot channel and berms of the stream. Although this structure has retained water from ordinary rains not exceeding 5 YRP, it eventually drains out through the interstitial spaces of the rocks that were piled up to form the embankment. The elevation of this dam reaches a height of almost $13 \mathrm{~m}$ above the main stream channel. The hydrologic analysis of this structure shows that is capable of retaining water volumes for rains up to $100 \mathrm{YRP}$, but is overtopped in a $500 \mathrm{YRP}$ event. If this occurs the structure will dramatically be breached causing major flooding downstream. This structure was intended to be a temporary solution due to the lack of water regulation downstream as a consequence of the La Fronteriza dam failure in 2006, but its poor construction and the lack of an emergency spillway, makes this structure a manmade hazard that jeopardizes life and property downstream.

\subsubsection{ERD La Fronteriza}

La Fronteriza dam was designed to regulate runoff volumes from the SDJ and avoid flooding-related problems downstream. This dam has a wall with a design height of $12 \mathrm{~m}$ from 
the stream's pilot channel to the dam crest. It has a riser spillway, outlet and an emergency spillway. The emergency spillway is no longer in use since several years ago poorly planned urban development allowed the construction of houses on top of the emergency channel. The original design storage volume of this dam was 300,000 $\mathrm{m}^{3}$, but sediment transport and accumulation has severely reduced its storage capacity by up to $90,000 \mathrm{~m}^{3}$ [3]. This structure failed by overtopping in 2006, when a 10 YRP rain occurred in the metroplex area. The spill over the crest was the consequence of the diversion of one tributary stream of the southernmost branch of the Arroyo Colorado. The water flow was diverted and connected downstream through a structure known as "La Gasera," which is a diversion wall and channel. The extra volume received by the La Fronteriza dam during the 2006 rain, coupled with the reduction of storage capacity due to sedimentation, resulted in the overtopping failure of this structure. Following this event, the dam's wall was intentionally breached with a channel with a hydraulic section and slope capable of transporting water flowing at rate of up to $70 \mathrm{~m}^{3} / \mathrm{s}$, as revealed by the hydrologic analysis.

\subsection{Hydraulics}

The bidimensional hydraulic modeling we carried out consisted of modeling two distinct scenarios. First, the November 4, 2016 rain, associated with a 2 YRP, was modeled. Once several pitfalls were identified in the ordinary rain modeling and hydrological results, a second rain scenario was modeled with a design storm associated with a 500 YRP rain event. The 500 YRP event would generate, according to the $1 \mathrm{D}$ hydrologic modeling results, a breaching scenario for El Filtro dam. This second scenario was designed to simulate the breaching or failure of El Filtro to evaluate both El Camino Real culvert operation and downstream effects.

The main result for the 2 YRP modeling showed the lack of water regulation at La Fronteriza dam is a relative concept since the width of the reservoir prevents all water from flowing freely downstream through the channel at $70 \mathrm{~m}^{3} / \mathrm{s}$, recording reservoir depths up to $2 \mathrm{~m}$ even for ordinary rains (Figure 3(a)). Nevertheless, this regulation is not sufficient since this drainage network branch is still the major contributing factor to the nearly $1 \mathrm{~m}$ water depths reached downstream of this location. In the same way, the bi-dimensional model at Pico del Aguila dam shows that this structure is properly regulating, reaching water depths of up to $1.60 \mathrm{~m}$ behind the dam. This is also the case for the Puerto La Paz dam, where runoff volume is properly regulated reaching depths of $1.80 \mathrm{~m}$ (Figure 3) behind the dam. Although this combined runoff flow regulation effectively diminishes the rate of water flowing downstream along this tributary stream, water depths of $0.40 \mathrm{~m}$ are still reached before the intersection of Las Viboras drainage with the RGR (Figure 3). This analysis also indicates that El Camino Real's culverts are retaining water, even for a $50 \%$ PE rain; a result not anticipated by the HMS modeling (Figure 3). Then, El Filtro dam is retaining, rather than regulating, a water volume flowing from the southern tributary watershed with a catchment area of nearly $6 \mathrm{~km}^{2}$. For heavier rains it is anticipated that this poorly constructed wall, lacking riser spillway and emergency spillway or outlets may fail, perhaps just increasing the hydrologic risk rather than reducing it as forecasted by the HMS modeling results. 
a)

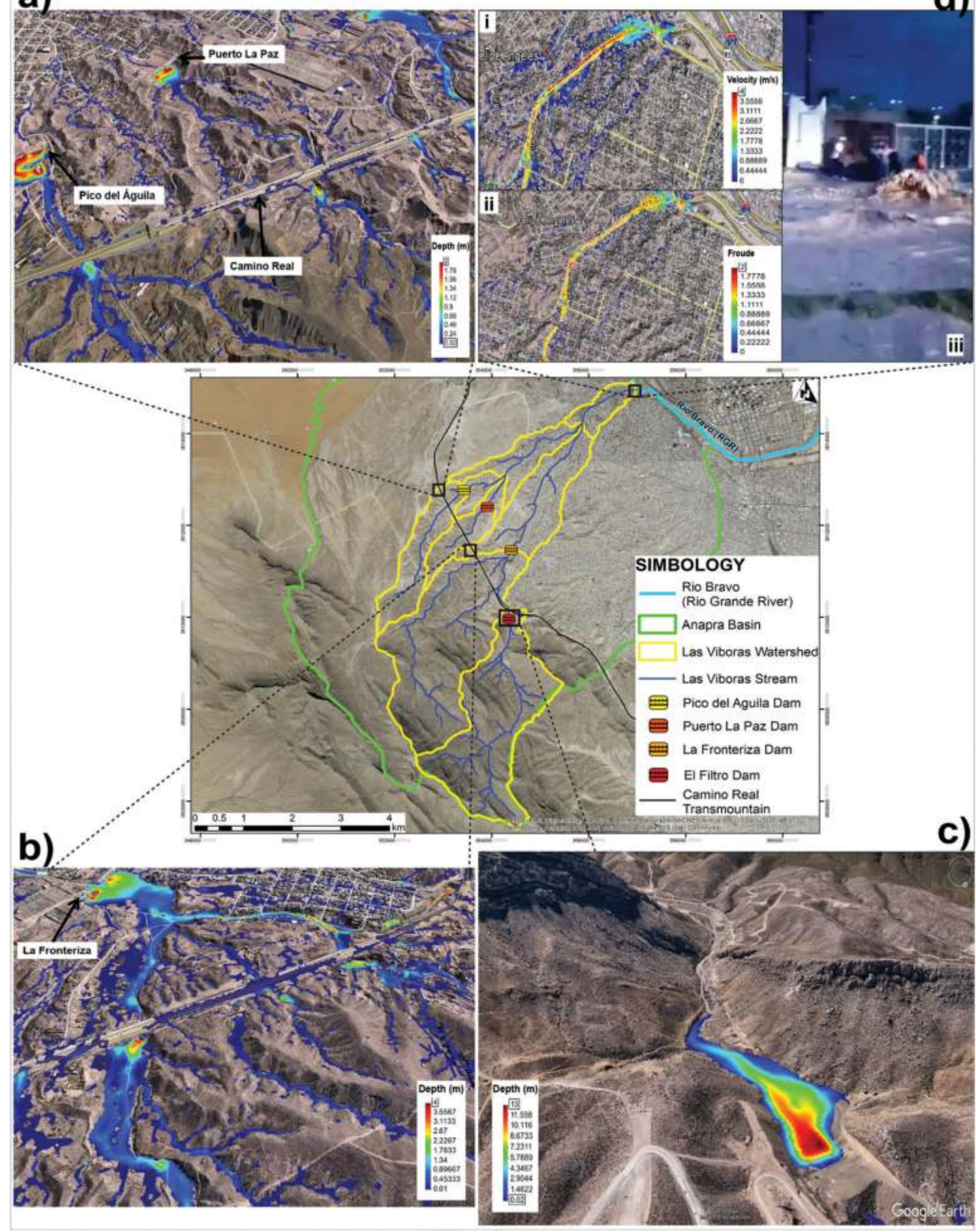

Figure 3. The results of 2D hydraulic modeling. (a) Water levels at Pico del Aguila and Puerto La Paz dams. (b) Water levels at culverts along El Camino and at La Fronteriza Dam. (c) Water levels at El Filtro Dam. (d) Velocity (i) and celerity (ii) results, (iii) turbulent flow at Las Viboras delivery point into Rio Grande River, photo taken by Azteca Noticias news. 
The velocity and celerity analysis downstream of Las Viboras system for a 2 YRP even shows that after the tributary and main channels have joined the flow velocity is high, recording values of $4 \mathrm{~m} / \mathrm{s}$ (Figure 3(i)). The celerity analysis resulted in Froude number is greater than 1 (Figure 3(ii)), thus a high velocity turbulent flow is present at Las Viboras' delivery point to the RGR. This is a consequence of the lack of proper regulation at the main channel due to the non-operational condition of La Fronteriza dam. The turbulent flow was the hydraulic feature that caused major damage in November 2016, causing severe economic and loss of life, not as consequence of an extreme rain event linked or related to climate change, but for an ordinary rain event with a $50 \%$ likelihood to occur yearly.

The second hydraulic scenario corresponds to El Filtro dam breaching for a 500 YRP event. The results are consistent with the hydrology, resulting in a runoff volume of $260 \mathrm{~m}^{3} / \mathrm{s}$ flowing through the simulated breach. This volume shows that the $4.5 \times 4.5 \mathrm{~m}$ culvert located downstream is not able to efficiently conduct the flow (Figure 4), yet the 1D calculations showed it as capable of transporting $360 \mathrm{~m}^{3} / \mathrm{s}$. The hydraulic jump generated at the upstream culvert opening reaches depths of $12 \mathrm{~m}$, so that El Camino Real's embankments act as a regulation dam, albeit they are not designed to do so. The detailed bi-dimensional modeling of the breached El Filtro dam-culvert system, also shows that the closed turn of the channel at the downstream culvert outlet produces turbulent and erosive velocities which are scouring the diversion wall of "La Gasera" located only $35 \mathrm{~m}$ to the north (Figure 4). As consequence of these results, the system was modeled again for a $2 \mathrm{YRP}$, but with the hypothetical scenario of removing El Filtro dam. The results show dramatic downstream effects; the downstream culvert is completely overtopped with water depths of $4 \mathrm{~m}$ both sides of the culvert, whereas water depths increase up to $2 \mathrm{~m}$ for the last branch of the drainage network. To conclude the hydraulic analysis, field work was conducted to identify erosional features such as gullies at the slope toe of "La Gasera" wall. The result was even more complex than predicted by the model; the wall scouring process related to several ordinary rain events show that the culvert is partially occluded with debris scoured from the wall. The hydraulic jump caused by the occlusion at the culvert outlet is recorded by water depths of nearly $3 \mathrm{~m}$, as shown by a water line traced upstream across the culvert passage (Figure 4).

\subsection{Geotechnical assessment}

Hydrological analysis is not the sole criteria to determine if a regulation dam is operating safely. Structural analysis is a key factor to provide an assessment of the structural integrity of the wall and foundations. Several methods were applied in this study to do this. First, a visual inspection of the wall showed very evident fractures and vertical displacements along the wall. This was followed up with other geological and geophysical analyses outlined below.

\subsubsection{Pico del Aguila}

A geological reconnaissance was carried out along the wall and reservoir perimeter. This showed no presence of solid bedrock, but only a tertiary polymictic conglomerate composed 


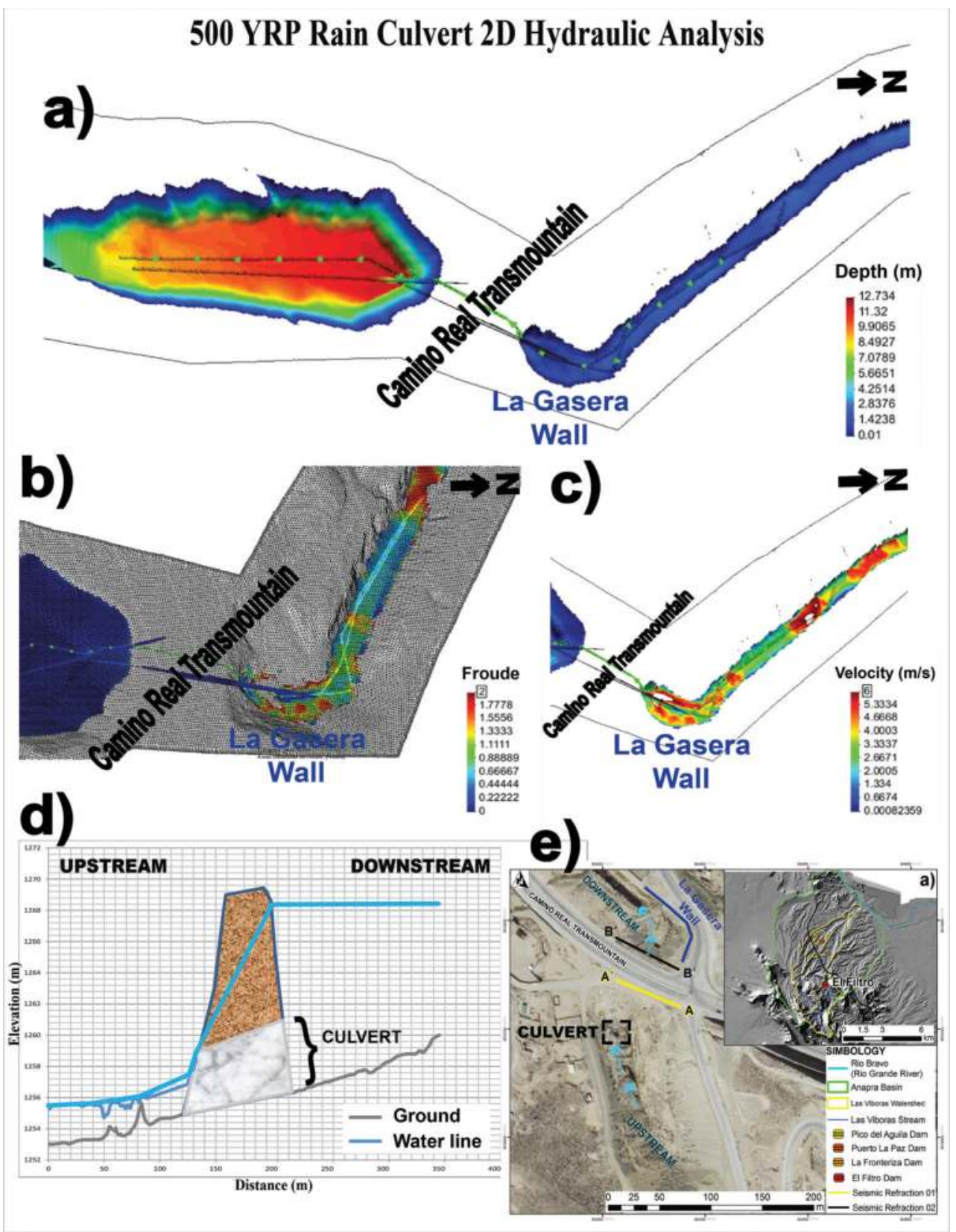

Figure 4. Hydraulic modeling results for the breaching of El Filtro dam. Inset (a) Water depth. Inset (b) Froude number. Inset (c) Velocity. Inset (d) Cross section showing how El Camino Real acts as retaining wall. 
of interlayered beds of sand, gravel, silts and clays [17]. Also, a visual inspection of the wall showed the presence of a displaced block in the vicinity of the spillway. This block is readily identifiable, even in recent satellite imagery. No fractures and/or cracks were observed elsewhere. The geoelectrical analysis (Figure 5) of the wall and foundations revealed that, in general, inside the wall body, an interbedded sequence of high, low and high resistivity values are observed. At depths greater than $10 \mathrm{~m}$ beneath the wall the structure seems to be resting on a foundation with high electrical resistivity. The electrical resistivity layers do not show a quasi-horizontal and homogeneous pattern. Layers are actually updipping between model coordinates (MC) 70 and $120 \mathrm{~m}$. At $130 \mathrm{~m}$ along the profile, a low-resistivity vertical anomaly is identified at the base of the wall. From 140 to $200 \mathrm{~m} \mathrm{MC}$ the layers are down dipping. Beyond $200 \mathrm{~m} \mathrm{MC}$ another vertical low-resistivity anomaly is observed. Besides showing a lower range in resistivity values, this anomaly is vertically propagated across the whole wall at MC $230 \mathrm{~m}$. This resistivity anomaly matches the location of the vertical down dropped block observed at the surface, atop of the wall crest. Finally, by the end of the section, the layers beneath the emergency spillway are quasi-horizontal, until a new vertical low-resistivity anomaly is found again at MC $265 \mathrm{~m}$.

The seismic data collected along this structure is a set of two refraction lines that were concatenated. The final $V p$ seismic section is displaced respect to the electrical tomography by $50 \mathrm{~m}$, meaning that the seismic starts at MC $50 \mathrm{~m}$ on the geoelectrical section. The compressional velocity field (Figure 5, center) shows the presence of a very low velocity layer of $400 \mathrm{~m} / \mathrm{s}$ along the whole seismic line, except at MC $140 \mathrm{~m}$ where this layer pinches out. The velocity field shows layers with velocities ranging between 400 and $600 \mathrm{~m} / \mathrm{s}$ from the surface to $8 \mathrm{~m}$ in depth. Below this depth a nearly quasi-horizontal layer of $650 \mathrm{~m} / \mathrm{s}$ bears the foundation of the wall. The seismostratigraphic pattern observed within the wall body (depths from 0 to $8 \mathrm{~m}$ ) is characterized by the presence of quasi-horizontal layers pinching out into a high velocity structure found at the middle of the section with values ranging between 600 and $700 \mathrm{~m} / \mathrm{s}$ where the isovelocity contour of $600 \mathrm{~m} / \mathrm{s}$ reaches depths of only $3 \mathrm{~m}$. No direct probing has been done at this structure to validate these nondirect methods and to assign these geophysical layers specific lithological and geotechnical parameters .

\subsubsection{ERD Puerto La Paz}

The geological reconnaissance of the topographic closure revealed no presence of bedrock flanks to anchor the structure. Actually, the only geologic unit identified both in the wall flanks and along the reservoir perimeter is a tertiary-age polymictic conglomerate composed of interlayered beds of sand, gravel, silts and clay [17]. Geophysical analysis of the wall and foundations through ERT (Figure 6, top) revealed that inside the wall body the strata are vertically displaced, as indicated by the undulating contact horizon geometry. The dam appears to rest on top of a very low resistivity $(<8 \mathrm{ohm}-\mathrm{m})$ non-homogeneous body located at $10 \mathrm{~m}$ depth. The seismic refraction analysis (Figure 6, middle) shows a vertical gradient in compressional velocities ranging from $350 \mathrm{~m} / \mathrm{s}$ at the top of the wall and $700 \mathrm{~m} / \mathrm{s}$ at the bottom of the originally designed wall that had a height $10 \mathrm{~m}$ above the river channel [1]. At depths greater than $10 \mathrm{~m}$ from the wall top, the velocity field reveals a ca. $800 \mathrm{~m} / \mathrm{s}$ structure. This 


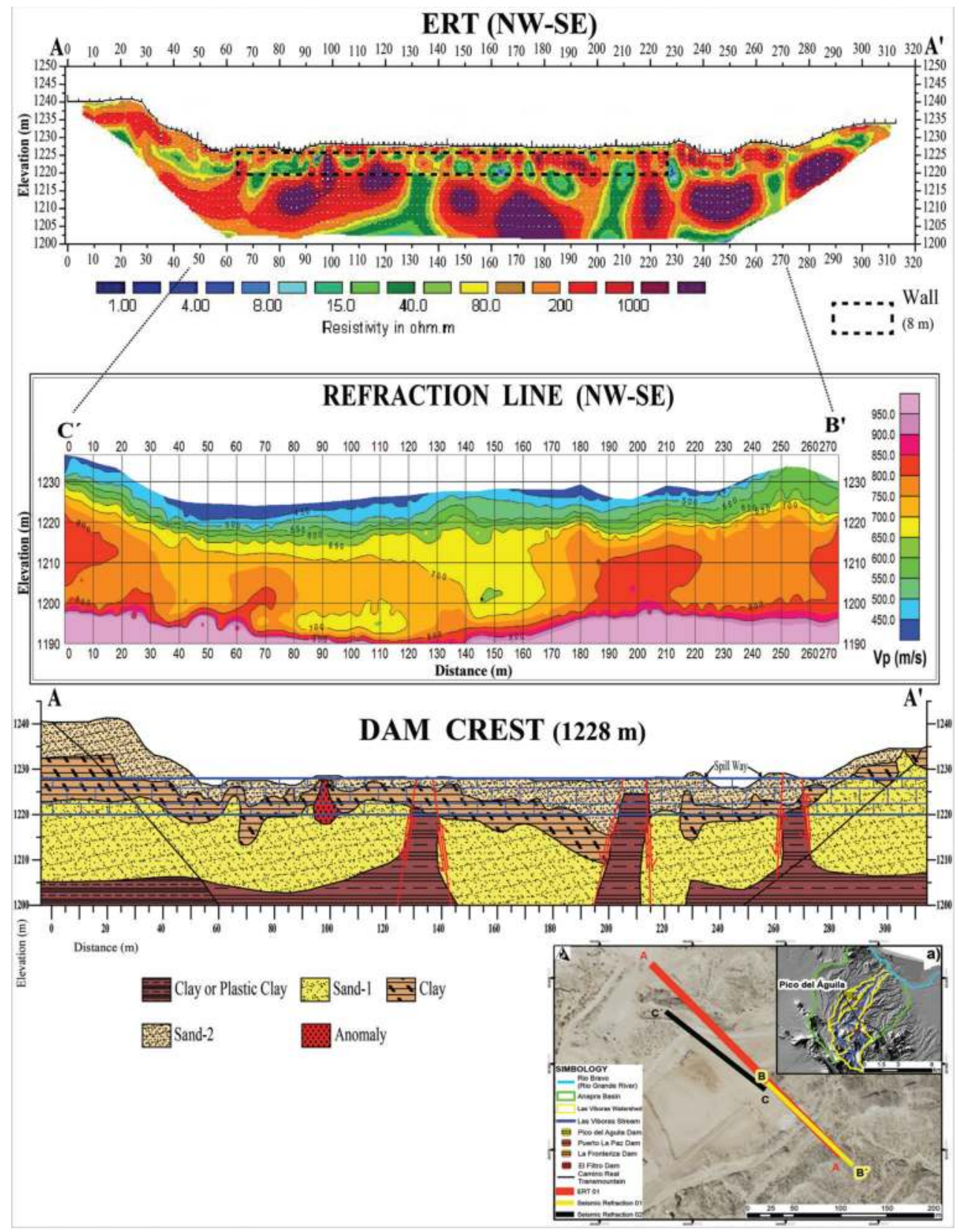

Figure 5. Geotechnical and geophysical assessment results at Pico de Aguila EDR. Top image: geoelectric profile. Middle image: $V$ p Refraction profile. Bottom image: interpreted results. Inset map at bottom shows location of geophysical surveys relative to extent of dam. 


\section{ERT (SE-NW)}
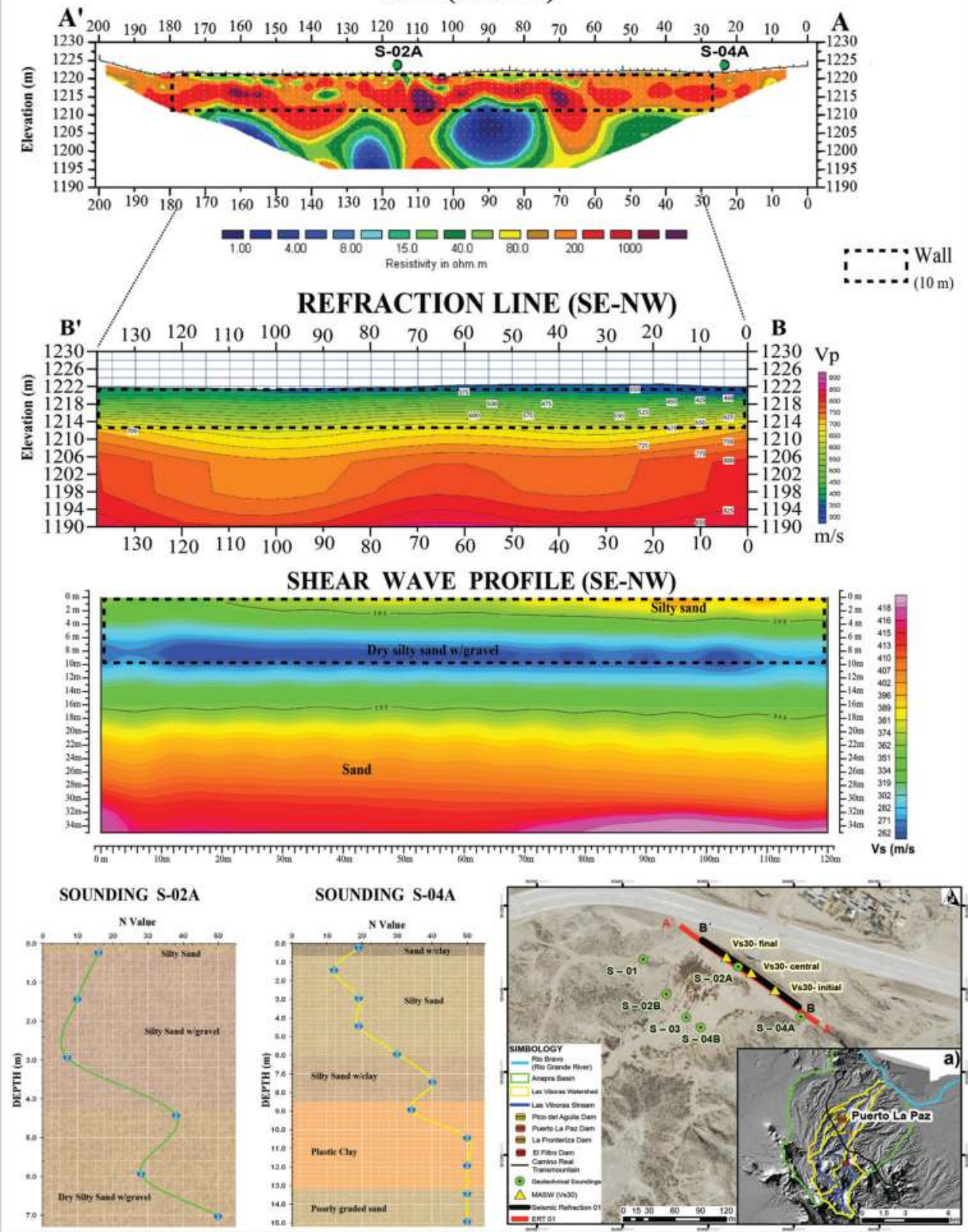

Figure 6. Geotechnical and geophysical assessment results for the Puerto de Paz dam. Top image: geoelectric profile. Position of soundings are indicated relative to dam are indicated. Middle Images top: Vp Refraction profile. Bottom image: $V$ s profile. Bottom left shows direct probing soundings. Bottom right shows geophysical and geotechnical survey locations with respect to the dam. 
feature matches the depth and location of the low resistivity $(<8 \mathrm{ohm}-\mathrm{m})$ body observed in the ERT profile. The Vs section (Figure 6) does not show the same behavior observed in the $V p$ field, i.e., a positive velocity gradient as function of depth. The S-wave velocity $(V s)$ field shows a $270 \mathrm{~m} / \mathrm{s}$ low shear velocity zone ( $L V \mathrm{sZ}$ ) located between depths of 6 and $10 \mathrm{~m}$. The velocities above the $L V s Z$ range from 360 to $380 \mathrm{~m} / \mathrm{s}$. The velocity field increases from $360 \mathrm{~m} / \mathrm{s}$ at a depth of $10 \mathrm{~m}$ to $420 \mathrm{~m} / \mathrm{s}$ at $20 \mathrm{~m}$ in depth. The $\mathrm{Vp} / \mathrm{Vs}$ and Poisson's ratios are respectively: 1.66 and 0.22 at depths of $4 \mathrm{~m}, 2.2$ and 0.37 at the $L V s Z$ and 2.34 and 0.39 at $10 \mathrm{~m}$ in depth.

Although direct soundings are available to validate the geophysics, there is only one sounding located atop the wall, and the maximum depth reached is $7 \mathrm{~m}$. This sounding reveals that the materials that form the wall are mainly silty sands. The load capacity parameter $\mathrm{N}$ from the standard penetration test (SPT) starts at 16 at the top of the wall and decreases to 7 at $3 \mathrm{~m}$ in depth, increases up to 38 blows at $4.5 \mathrm{~m}$ and decreases again to 28 at a depth of $6 \mathrm{~m}$. Another sounding is also available at the right shoulder of the wall. This sounding shows the presence of silty sands forming the body of the wall, but since this sounding goes deeper, it records plastic clays at the bottom of the dam wall, which corresponds to the resistivity values of less than 8 ohm-m observed at these depths.

\section{Discussion}

\subsection{ERD Puerto La Paz}

The regulation dam Puerto La Paz is hydrologically capable of handling rains up to 500 YRP, but is hydraulically compromised for a 10,000 YRP volume since the emergency spillway flow exceeds the required freeboard of at least $0.91 \mathrm{~m}$, as required by the Bureau of Reclamation and Mexican law. Although this dam seems to be able to handle runoff volumes even for nonordinary rains, its structural condition, as revealed by the geotechnical assessment through geoelectrical, seismic studies and direct soundings, is seriously compromised. The wall's foundation rests on top of a thick plastic clay layer which seems to have experienced differential loading effects resulting in the wall's very poor condition observed at surface. Furthermore, the tomographic geoelectrical profile (Figure 6) shows quasi-vertical strata displacements matching the displacements observed at surface. The most evident displaced layer is a high resistivity unit of $200 \mathrm{ohm}-\mathrm{m}$ atop a very low resistivity unit $(<8 \mathrm{ohm}-\mathrm{m})$ interpreted as plastic clay as a result of the correlation of the direct soundings with geophysics. Therefore, this structure poses a serious hydrological hazard, which combined with the overpopulated, lowincome neighborhoods located downstream, significantly increases the risk as a consequence of population vulnerability.

\subsection{ERD Pico del Aguila}

Although no direct geotechnical data are available for this dam, the geological scenario, which is similar to the Puerto La Paz (PLP) dam since it is located only $1 \mathrm{~km}$ from Pico del Aguila, allows us to make a correlation of electro-stratigraphic and seismo-stratigrafic units with 
specific lithologies found by direct exploration at the Puerto La Paz (PLP) dam. The interpreted lithological section (Figure 5, bottom image) shows that the body of the wall would be then composed of an interlayered sequence of silty sands associated with resistivities greater than $200 \mathrm{ohm}-\mathrm{m}$. The interbedded stratum with resistivity values between 15 and $60 \mathrm{ohm}-\mathrm{m}$ is associated with a sandy clay unit. A nearly vertical high resistivity anomaly, located at M.C. $90 \mathrm{~m}$, is perhaps associated with the presence of an abandoned concrete sewer line emplaced across the dam's body. Foundation of the dam is resting on a very high electrical resistive package (>1000 ohm-m) associated with clean sands and or gravel. Seismically, the interbedded sequence is not observed, but this might be a limitation of the method, unable to model velocity inversions [21]. But in contrast, a positive velocity gradient, starting at $350 \mathrm{~m} / \mathrm{s}$ at the surface and increasing to over $700 \mathrm{~m} / \mathrm{s}$ at the wall bottom, is observed in the velocity field. The $V \mathrm{p}$ values at the foundation horizon are then defined by the $700 \mathrm{~m} / \mathrm{s}$ isovelocity contour, interpreted as associated with Tertiary sediments composed by sand and gravel, which makes it a competent strata. Although the foundation layer is competent, the presence of the highly warped region of $600-700 \mathrm{~m} / \mathrm{s}$ Vp velocities in the middle of the seismic section, reveals that the material forming the body of the wall was severely perturbed by deformation and movement. These materials appear to have been re-emplaced and compacted "a-posteriori." This process definitely does not lead to proper linkage or anchoring of the original layering to the recently emplaced material. This feature must be considered a serious flaw, which seriously compromises the structural integrity of the wall. Furthermore, the quasi-vertical low resistivity anomalies indicate clay bodies are intruding the structure in as similar fashion to that observed within the Puerto La Paz dam wall. Although no direct probing of the material is available, these inferred clay structures compromise the structural integrity of the wall, as evidenced by cracks and openings propagated along the wall slope at the same location as the clay bodies that are revealed by the geoelectrical data.

\section{Conclusion}

The geological, geophysical and geotechnical assessment of El Camino Real road culverts and dams revealed that, as expected, El Camino Real structure is not designed to prevent internal erosion; that the Puerto La Paz and La Fronteriza dams were severely compromised and it was definitively necessary to breach them. The El Filtro dam is also structurally compromised and poses a major danger if a 500 YRP event occurs again. This analysis also showing that the Pico del Aguila dam is structurally compromised. Finally, the 500 YRP modeling of Las Viboras watershed under actual conditions reveals that El Filtro dam would be breached due to hydrostatic pressure and overtopping. Hence, the risk for a 500 YRP event is severely increased downstream as consequence of failure of the dam.

In terms of risk, if we consider the risk function as defined as the concatenation of three elements: conditional elements, triggering elements and vulnerability [23], then the structurally compromised dams, geology and abrupt topography are the conditional factors, whereas the extreme and ordinary hydro-meteorological events are the triggering elements. On the other hand, the overpopulated neighborhoods represent the vulnerability element, which all 
together define Las Viboras specific risk function. On this point, this study has detailed proven that from a structural and hydrological point of view, the hydraulic operation of earthen regulation dams is seriously compromised for any rain event (not necessarily an extreme rain event). Then, the hazard function resulting from joining conditional and triggering elements is high. This hazardous condition, linked to the overpopulated neighborhoods, with more than 30,000 people, located downstream of Las Viboras dams, constitutes and even higher risk function. While Las Viboras Dam is perhaps the most complicated watershed in terms of flooding, the vulnerability element (people), should be analyzed for the whole Juarez-El Paso Metroplex system, with nearly 2 million people. Then, although each watershed is modeled independent, the final results should be portrayed including the system as a whole, considering three key elements:

(1) Modeling and design of hydraulic infrastructure with 1000 YRP rains as consequence of climate change effects, which have shortened the occurrence interval for heavy rain events.

(2) Anapra basin drainage outlets directly into the Rio Grande, posing a risk not only for Las Viboras population but also for El Paso downtown area if a heavy rain event occurs, since the RGR is not going to be able to handle this runoff coupled with runoff from other regions upstream.

(3) The hydrologic effect of a planned $\sim 10 \mathrm{~m}$ high border wall that will be placed on the United States river bank to decrease the flow of undocumented immigrants from Mexico also needs to be examined. It is likely to prevent flood water from reaching downtown El Paso, but will increase the flooding risk to Mexico as water will be deflected into downtown Juarez. In addition, if the border wall is not designed as a water retention structure capable of bearing hydrostatic load, then failure of the wall in an extreme rain event could be catastrophic for El Paso.

In terms of resilience, we adopted the socio-hydrologic resilience framework [24], since it incorporates the interaction between social and hydrologic elements as a system, considering not only the effect of human activity on the hydrologic ecosystem but also the impacts of the hydrology on the society. The socio-hydrologic resilience is then more precisely defined as a function of three system's capacities: absorptive or tolerance capacity, adaptation or response capacity and transformation or ability to change capacity. Once a more detailed ad hoc resilience definition was available we compared the tree capacities for two specific tempo-rain scenarios for Las Viboras system: 2006 with a 10 YRP and 2016 with a 2 YRP.

In 2006, for a $10 \mathrm{YRP}$, the resilience function, shows how the manmade diversion of the Colorado River at La Gasera wall, stimulated a undesired hydrological adaptation of the system that caused severe erosion paths due to the nearly $90^{\circ}$ deflexion channel curvature at La Gasera wall, and an excessive storage volume that resulted in an overtopping failure of La Fronteriza Dam in 2006. The other hydraulic structures at Las Viboras system operated satisfactorily. Therefore, we may conclude that the socio-hydrologic resilience function in 2006 was nearly enough for a 10 YRP rain event. This means that even though the system did not 
fully absorb the rain event, it certainly buffered it with a satisfactory rain-runoff conversion. In terms of the nonanticipated system adaptation, widening channels and erosion were properly absorbed too, but not the excessive transported volume of water that overtopped a dam. Thus, the transformation capacity (i.e., ability to change with infrastructure) operated nearly properly by compensating, maybe on the safety edge, but still properly, since no problems were reported downstream, although La Fronteriza dam's breaching risk was imminent once it started to overtop.

In 2016, the presence of the Camino Real with sub-dimensioned culverts, the non-operational condition of La Fronteriza Dam and the structurally compromised Puerto La Paz, Pico del Aguila and El Filtro dams constitute a decrease in the transformation capacity. The absorption or tolerance capacity has also decreased since paving process has increased impervious surfaces. Then, if transformation and absorption capacities have been diminished, the hydrologic adaptation of the system has resulted in 2016 in very negative effects that were not present on the susceptibility inventory in 2006. First, erosion of materials of the down slope of La Gasera wall has nearly blocked the Camino Real culvert downstream of El Filtro dam and culverts along the Camino Real are retaining water as shown by the 2D modeling even for ordinary rains. La Fronteriza dam's lack of regulation conveys high water volumes of water and sediments from a nearly $4 \mathrm{~km}^{2}$ watershed. This resulted in water depths reaching $1.4 \mathrm{~m}$ at Las Viboras highly urbanized discharge area. High velocity and turbulent flows were present downstream along the whole main stream. The turbulent flow has practically mechanically destroyed the once claimed "water resistant" hydraulic concrete road surface near the watershed outlet, because this concrete can bear laminar flows but not the mechanical stress superimposed by turbulent flows. Also, the non-laminar flows and high transport velocities of heavy sediment loads resulted in the mechanical destruction of the underground sewer line with an immediate cost of nearly $25 \mathrm{M}$ USD. And finally, not only property loss has been reported as consequence of high velocity and turbulent flows but also life loss, since two people were killed by or as consequence of the November ordinary rain event.

In summary, Las Viboras System was considerably less sociohydrologic resilient in 2016 than in 2006. This is a direct consequence of a multifactorial function where the poor local governance is the common denominator. In other words, the almost non-existent maintenance hydraulic structures maintenance, poor urban planning (i.e., developing even more house complexes downstream) and the lack of political will and compromise to foresee the need of hydraulic infrastructure in major city that is prone to flashflooding, have resulted in zero lobbying to access available federal resources. Thus, as consequence, this watershed is not even able to properly manage 2 YRP runoff volumes. This means that socio-hydrologic resilience function is practically null, since even ordinary rain events claim property and life loss.

This diagnosis reveals that the solution for this watershed is to increase the socio-hydrologic resilience by focusing on the transformation capacity, rather than in the absorption and the long-term adaptation capacities. Three dams have to be constructed upstream of the current dams' locations. These new dams would be located between highly competent rock flanks and rock basement to ensure structural stability, in order to warrant hydrological regulation and retention of fine grained, water suspended sediments. These three dams would replace 
El Filtro dam, which is more a risk than a protection, and the non-operational La Fronteriza dam, which should not be rebuilt at the same location due to the high volumes of sediment that have severely diminished its storage capacity. The Pico del Aguila dam, although working properly for ordinary rains, should be rebuilt with an emergency spillway to transit the hydrogram peak associated with a 10000 YRP rain; this will ensure its hydraulic and structural safety. The Puerto La Paz dam is completely ruined, with evident gullies exposed at the surface and internal erosional features and a poor foundation as revealed by geophysical methods. However, based on hydrological considerations, a new dam is required in the same area. The geophysics carried out at the containment area has revealed that competent Tertiary conglomerates lacking plastic clays are located 100 meters upstream. 1D modelling of the hydrology with the wall displaced $100 \mathrm{~m}$ upstream shows that the structure would still be able to store and regulate volumes associated up to a 1000 YRP event and safe transport of water from a $10000 \mathrm{YRP}$ event if a proper emergency spillway is emplaced. This technical solution is the key component for the system to change to an equilibrium or resilient condition. Finally, absorption capacity should be increased or at least preserved with the design of a resilient master plan for urbanization for the whole watershed. In addition, the adaptation capacity should be viewed not only as the response of the system under change or stress conditions, but also as the ability to learn from previous flood events and understand that the socio-hydrological system is a two-way road. If we impact the hydrology, the system response will have a later impact on society, so a great effort focused on education and outreach is definitely necessary to insure increasing resiliency to flash flooding events.

\section{Author details}

Oscar Sotero Dena Ornelas ${ }^{1 *}$, Diane Irene Doser², Oscar Fidencio Ibañez Hernández ${ }^{1}$, Griselda Janeth Obeso Cortez ${ }^{1}$ and Miguel Angel Galdean Vega ${ }^{1}$

*Address all correspondence to: oornelas@uacj.mx

1 Universidad Autónoma de Ciudad Juárez, Ciudad Juárez, México

2 University of Texas at El Paso, El Paso, USA

\section{References}

[1] Comisión Nacional del Agua. Estudio de Factibilidad para el control Integral de avenidas en las cuencas Zona I Anapra y Zona II Centro en Ciudad Juárez. 1st ed. Ciudad Juárez: CONAGUA; 2009. 255 p

[2] Instituto Municipal de Investigación y Planeación. Plan Sectorial de Manejo de Agua Pluvial. 1st ed. Ciudad Juárez: Instituto Municipal de Investigación y Planeación; 2004. $384 \mathrm{p}$ 
[3] Instituto Municipal de Investigación y Planeación. Atlas de Riesgo de Ciudad Juárez. 2nd ed. Ciudad Juárez: Instituto Municipal de Investigación y Planeación; 2016. 420 p.

[4] Haenggi W. Tectonic history of the Chihuahua trough, Mexico and adjacent USA, Part II: Mesozoic and Cenozoic. Mexican Geological Society Bulletin. 2002;1(L):38-94

[5] PEMEX. Provincia Petrolera de Chihuahua. PEMEX Exploración y Producción, Subdirección de Exploración. 2013;1(1)

[6] Keaton J, and Barnes J. Paleoseismic Evaluation of the East Franklin Mountains Fault, El Paso, Final Report,. 3rd ed. Texas: U.S. Geological Survey National Earthquake Hazards Reduction Program; 1996. 134 p

[7] Collins E, and Raney J. Tertiary and quaternary structure and paleotectonics of the Hueco Basin, trans-Pecos Texas and Chihuahua, Mexico. Bureau of Economic Geology. 1991;2(91):44

[8] Drewes H, and Dyer R. Geological map and structure sections of the Sierra Juárez, Chihuahua, México. U. S. Geological Survey Miscellaneous Investigations. 1993;2287(1):2

[9] Dena O, Obeso G, Leyva J, Domínguez M, Hernández V, Granados A, and De la Cruz S.Estudio geológico y geofísico de la ladera sur del corte del mirador Hidalgo en Ciudad Juárez, Chihuahua. Ingeniería, Investigación y Tecnología. 2011;12(4):439-459. DOI: 14057743

[10] Loke M. Electrical Imaging Surveys for Environmental and Engineering Studies. 1st ed. Swedich: LUND University; 2000. 31 p

[11] Yilmaz O. Engineering seismology with applications to geotechnical engineering. Investigations in Geophysics: Society of Exploration Geophysicist. 2015;71(3):371-512

[12] Ackerman C. HEC-GeoRAS GIS Tools for Support of HEC-RAS using ArcGIS User's Manual. 1st ed. USA: U.S. Army Corps of Engineering Hydrologic, Hydrologic Engineering Center; 2011. $97 \mathrm{p}$

[13] Scharffenberg W, Flemming M. Hydrologic Modeling System HEC-HMS User's Manual. 2nd ed. USA: U. S. Army Corps of Engineers Hydrologic Center; 2010. 305 p

[14] Hydrologic Modeling System HEC-HMS Application Guide. 11th ed. USA: U.S. Army Corps of Engineers Hydrologic, Hydrologic Engineering Center; 2008. 97 p

[15] Myrland J. Two-dimensional hydraulic modeling for flood assessment of the Rio Rocha, Cochabamba, Bolivia [thesis]. Uppsala University: Department of Erath Sciences Program of Air, Water and Landscape Science; 2014. 200 p

[16] Palacky G. Resistivity characteristics of geological targets. In: Nabighian M, editor, Electromagnetic Methods in Applied Geophysics-Theory. Society of Exploration Geophysiscist. 1987;5(3):53-129

[17] Servicio Geologico Mexicano. Carta Geologica y Magnética de Campo Total Escala 1:50,000 de Ciudad Juárez, Chihuahua. 1st ed. Chihuahua: SGM; 2008. 2 p 
[18] Dahlin T, and Linderman J. ERIGRAPH Software Developed in Cooperation between ABEM. 1st ed. Lund University and Terraohm: ABEM; 2007. $60 \mathrm{p}$

[19] Loke M. TUTORIAL: 2-D and 3-D Electrical Imaging Surveys. 2nd ed. LUND University: ABEM; 2004. $31 \mathrm{p}$

[20] Essien U, Akankpo A, Igboekwe M. Poisson's ratio of surface soils and shallow sediments determined from seismic compressional and shear wave velocities. International Journal of Geoscience. 2014;5(5):1540-1546. DOI: 10.4236/ijg.214.512125

[21] Prem V. Sharma. Environmental and Engineering geophysics. 1st ed. University of Copenhagen: Cambridge University Press; 1997. 477 p. DOI: $10.1017 / C B O 9781139171168$

[22] Dahlin T, Sjödahl P, Friborg J, and Johansson S. Resistivity and SP surveying and monitoring at the Sädva Embakment Dam, Sweden. In: Procs. 5th European ICOLD Symposium; 25-27 June; Geiranger, Norway: Lund University of Technology; 2001. pp. 107-113

[23] González V, Ferrer M, Ortuño L, and Oteo C. Ingenieria Geologica. 1st ed. Madrid, España: Prentice Hall; 2002. 744 p

[24] Mao F, Clark J, Karpouzoglou T, Dewulf A, Buytaert W, and Hannah D. A Conceptual Framework for Assessing Socio-Hydrological Resilience under Change. Hidrology and Earth System Sciences, European Geosciences Union. 2016;DOI: 10.5194/hess-2016-499 
